\title{
Revised Description, from Clinical Isolates, of Flavobacterium odoratum Stutzer and Kwaschnina 1929, and Designation of the Neotype Strain
}

\author{
B. HOLMES, J. J. S. SNELL, AND S. P. LAPAGE \\ National Collection of Type Cultures, Central Public Health Laboratory, London NW9 5HT, \\ United Kingdom
}

\begin{abstract}
Flavobacterium odoratum Stutzer and Kwaschnina 1929 was originally meagerly described. No type strain was designated, and the species does not appear to have been referred to in the literature since it was first described. We have examined a reference strain (ATCC $4651=$ NCTC 11036) of this species, one of Stutzer's strains, which we propose as the neotype strain. Of 1,500 gram-negative, non-fermentative isolates submitted to the National Collection of Type Cultures for computer-assisted identification over the last 10 years, nine conformed in their characters to the proposed neotype strain of $F$. odoratum. We have examined these strains in a large number of biochemical tests and in susceptibility to a range of antimicrobial agents in order to give a revised description of the organism by which it may be more easily recognized in clinical material. All 10 isolates of $F$. odoratum were resistant to gentamicin and carbenicillin as well as to several other antimicrobial agents generally useful in the treatment of infections caused by gram-negative, non-fermentative organisms, and this suggests that infections due to this organism might prove difficult to treat.
\end{abstract}

The name Flavobacterium odoratum was given by Stutzer and Kwaschnina (19) in 1929 to strains which they had isolated from the feces of patients with intestinal infections. In 1923, Stutzer (18) called this organism Bacterium faecale aromaticum, but he later (19) changed the name to $F$. odoratum to conform to the Rules of Botanical Nomenclature as given in Bergey's Manual of Determinative Bacteriology (1). F. odoratum is not listed in the latest edition of Bergey's Manual of Determinative Bacteriology (22) and it did not appear in any preceding edition (except under the illegitimate name Flavobacterium fecale Bergey et al. 1930, a later synonym). Neither is $\boldsymbol{F}$. odoratum listed in $\mathbf{I n}$ dex Bergeyana (5), and, as far as we have been able to determine, there have been no references to $F$. odoratum in the literature since it was first described. The organism would probably have remained in obscurity had there not been a reference strain of the species-one of Stutzer's strains-maintained by the American Type Culture Collection (ATCC) under the number 4651.

The present account reports the results of biochemical tests, antimicrobial susceptibility tests, and determinations of deoxyribonucleic acid (DNA) base compositions obtained from an examination of the reference strain maintained at the ATCC and nine field isolates submitted to us for identification. Clinical details relating to the isolation of the nine field isolates are also reported.

\section{MATERIALS AND METHODS}

Bacterial strains. The identities and sources of the 10 strains studied are given in Table 1.

Strain 1, from the urine of a 48-year-old female, was isolated together with a strain of Pseudomonas fluorescens, and this makes it likely that the urine specimen was contaminated rather than infected. It is not known if the urine contained pus. The clinical notes mention cystitis, treated with furadantin, at the time the organism was isolated, but there did not appear to be any suggestion of chronic or recurrent urinary tract infection. This isolate, therefore, did not appear to be clinically significant.

Strain 2 was isolated from an infected cut on the finger of a 34-year-old male; further details are not available.

Strain 3 was isolated from a urine specimen taken from a 59-year-old female, but the organism was present in such low numbers that it was considered a contaminant. Further urine specimens were sterile.

Strain 4 was isolated from the urine of a female patient who was admitted complaining of urinary retention of unknown origin. The patient was catheterized frequently over a 6-month period and was found to have a urinary tract infection caused by Escherichia coli. Strain 4 was isolated from one specimen only of urine while the catheter was in situ. Subsequent urine examination showed continued urinary tract infection with $E$. coli, and it was therefore felt that strain 4 was not clinically significant.

Strain 5 was also isolated from urine. Further details are not available.

Strain 6 was grown from a wound swab of a varicose ulcer; further details are not available.

Strain 7 was isolated from an ulcer on the right 
TABLE 1. Bacterial strains studied

\begin{tabular}{llll}
\hline \multicolumn{1}{c}{ Strains } & $\begin{array}{c}\text { Original strain } \\
\text { designation }\end{array}$ & \multicolumn{1}{c}{ Source } & Site of isolation \\
Field strains & CL41/66 & J. G. Wallace, Northallerton & Urine \\
1 & CL229/67 & M. P. Jevons, London & Wound swab \\
2 & CL44/74 & G. A. Fenwick, Newcastle upon Tyne & Urine \\
3 & CL475/74 & E. J. Crummy, Dublin & Urine \\
4 & CL554/74 & K. M. Elhag, London & Urine \\
5 & CL607/74 & H. Andrews, London & Wound swab \\
6 & CL103/75 & J. Dannatt, Scunthorpe & Leg ulcer \\
7 & CL588/75 & D. J. M. Wright, London & Urine \\
8 & CL164/76 & P. Kohút and M. Rusinko, Bratislava, & Urine \\
9 & & Czechoslovakia & \\
Culture collection & & & \\
strain & & ATCC & Unknown \\
ATCC 4651 & & &
\end{tabular}

${ }^{a}$ Strain deposited in American Type Culture Collection (ATCC) by D. H. Bergey, who received it from M. J. Stutzer.

thigh of a 76 -year-old female. At the time of isolation of the strain, the patient had had the ulcer, which was said to have started after a gnat bite, for about 14 months. The ulcer was excised and showed the presence of a superficial low-grade malignancy.

Strain 8 was isolated in a mixed culture from a urine specimen containing 50 white cells per $\mathrm{mm}^{3}$. The urine contained between $10^{4}$ and $10^{5}$ cells of strain 8 per $\mathrm{ml}$ and also a lactose-fermenting coliform which was not further identified. The patient, a 67-year-old female with multiple carcinomas, had had a total cystectomy and ileal loop urethrotomy in 1967. She was admitted towards the end of 1975 with a breast lump and had an uncomplicated mastectomy; strain 8 was isolated at this time. The patient was discharged suffering from metastatic bone disease.

Strain 9 was isolated from a urine specimen from a 48-year-old male suffering from chronic renal insufficiency with a history of left pyelonephritis and repeated renal calculi. The patient developed symptoms of renal hypertension and uremia, with secondary renal anemia and oliguria.

Strain 9 was isolated from the urine in mixed culture with Proteus mirabilis. Pseudomonas aeruginosa was also isolated from repeated blood cultures. The patient died 2 weeks after admission to the hospital.

Bacteriological investigations. The bacteria were subcultured on nutrient agar (Oxoid CM 67, 25 $\mathrm{g}$; New Zealand agar, $12 \mathrm{~g}$; 1,000 $\mathrm{ml}$ of distilled water) under aerobic conditions for 18 to $24 \mathrm{~h}$ at their optimum growth temperature, $37^{\circ} \mathrm{C}$. Colonial morphology was described from aerobic growth on nutrient agar and on $5 \%$ (vol/vol) horse blood agar. Pigmentation was recorded from growth on nutrient and tyrosine agar, and fluorescence was tested for on medium B of King et al. (11). The Gram reaction was determined by Lillie's modification as described by Cowan (6). Motility was tested for by the hanging-drop method on overnight culture grown at room temperature (18 to $22^{\circ} \mathrm{C}$ ) and at $37^{\circ} \mathrm{C}$ in nutrient broth (Oxoid CM 67).

The biochemical characteristics investigated are listed in Tables 2, 3, and 4. The methods used for these tests were described previously by Holmes et al. (10) with the following changes or additions: indole
TABLE 2. Biochemical characteristics of Flavobacterium odoratum: tests for which all strains are positive

Alkaline reaction in O-F test
Casein digestion
Catalase production
Cytochrome-oxidase production
Deoxyribonuclease production
Gelatinase production ${ }^{\alpha}$
Growth at $37^{\circ} \mathrm{C}$
Growth at room temp
Growth on $\beta$-hydroxybutyrate
Growth on MacConkey agar
Growth on triphenyl-tetrazolium chloride agar
Nitrite reduction
Phosphatase production
Production of yellow pigment
Tween 20 hydrolysis
Urease production

${ }^{a}$ By plate method.

${ }^{b}$ Room temperature, 18 to $22^{\circ} \mathrm{C}$.

production was tested for with Kovács reagent, and with Ehrlich reagent by method 3 of Cowan (6); phosphatase production was determined by method 1 of Cowan (6); acid production was also tested for in O-F medium containing carbohydrates at a concentration of $1 \%(\mathrm{wt} / \mathrm{vol})$; and growth inhibition by $0.1 \%(\mathrm{wt} / \mathrm{vol})$ 2:3:5 triphenyl-tetrazolium chloride (Koch-Light Laboratories Ltd., Colnbrook, England) incorporated in nutrient agar was also tested.

Susceptibility to antimicrobial agents was tested by use of an agar dilution method. Twofold dilutions of antimicrobial agents were added to Diagnostic Sensitivity Test agar (Oxoid Ltd., London) to give a range of concentrations of 128 to $0.006 \mu \mathrm{g} / \mathrm{ml}$. Lysed horse blood $(2 \% \mathrm{vol} / \mathrm{vol})$ was added to medium containing sulfonamide and co-trimoxazole. The medium was dispensed into petri dishes which were inoculated, using a replicating device, with $0.003-\mathrm{ml}$ volumes of overnight broth cultures of bacteria diluted to contain about $10^{5}$ cells per ml. Each plate was also inoculated 
with three control strains of known susceptibility: Escherichia coli NCTC 10418; Pseudomonas aeruginosa NCTC 10662; and Staphylococcus aureus NCTC 6571. The minimum inhibitory concentration of an antimicrobial agent for each strain was defined as the lowest concentration completely inhibiting growth after overnight incubation at $30^{\circ} \mathrm{C}$.

DNA base compositions. DNA was extracted by the method of Marmur (14) and was further purified by treatment with protease and phenol as described by Brenner et al. (4). The melting temperature $\left(T_{m}\right)$ determinations were made in standard saline citrate buffer $(1.0 \times \mathrm{SSC})$ in a Pye Unicam SP 1800 spectrophotometer equipped with an electrically heated cell holder and a temperature programmer. The temperature of the DNA was raised at the rate of $0.25^{\circ} \mathrm{C} / \mathrm{min}$,

TABLE 3. Biochemical characteristics of Flavobacterium odoratum: tests for which all strains are negative

\begin{tabular}{|c|c|}
\hline $\begin{array}{l}\text { Acid from the following } \\
\text { ammonium saltsugars: }\end{array}$ & Arginine dihydrolase \\
\hline $\begin{array}{l}\text { ammonium salt sugars: } \\
\text { Adonitol }\end{array}$ & $\begin{array}{l}\text { Esculin hydrolysis } \\
\text { Fluorescence on King medium }\end{array}$ \\
\hline $\begin{array}{l}\text { Adonitol } \\
\text { Arabinose }\end{array}$ & $\begin{array}{l}\text { Fluorescence on King medium } \\
\mathrm{B}\end{array}$ \\
\hline $\begin{array}{l}\text { Arabinose } \\
\text { Cellobiose }\end{array}$ & Gas from PWS glucose \\
\hline Dulcitol & Gluconate oxidation \\
\hline Ethanol & Growth at $5^{\circ} \mathrm{C}$ \\
\hline Fructose & Growth at $42^{\circ} \mathrm{C}$ \\
\hline Glucose & Growth on cetrimide \\
\hline Glycerol & Growth on $6 \%(\mathrm{wt} / \mathrm{vol}) \mathrm{NaCl}$ \\
\hline Inositol & Growth on Simmons citrate \\
\hline Lactose $^{\alpha}$ & Hydrogen-sulfide production \\
\hline Maltose $^{a}$ & Indole production ${ }^{i}$ \\
\hline Mannitol $^{\alpha}$ & $\mathrm{KCN}$ tolerance \\
\hline Raffinose & Lysine decarboxylase \\
\hline Rhamnose & Malonate utilization \\
\hline Salicin & Motility \\
\hline Sorbitol & Nitrate reduction \\
\hline Sucrose $^{n}$ & Opalescence on lecithovitellin \\
\hline Trehalose & agar \\
\hline Xylose $^{n}$ & Ornithine decarboxylase \\
\hline Acid from $\mathrm{PWS}^{b}$ glucose & Phenylalanine deamination \\
\hline $\begin{array}{l}\text { Acid from } 10 \% \text { (wt/vol) } \\
\text { glucose }\end{array}$ & $\begin{array}{l}\text { Poly- } \beta \text {-hydroxybutyrate inclu- } \\
\text { sion granules }\end{array}$ \\
\hline $\begin{array}{l}\text { Acid from } 10 \%(\mathrm{wt} / \mathrm{vol}) \\
\text { lactose }\end{array}$ & $\begin{array}{l}\text { Reduction of } 0.4 \%(\mathrm{wt} / \mathrm{vol}) \text { sel- } \\
\text { enite }\end{array}$ \\
\hline $\begin{array}{l}\text { Alkali production on Chris- } \\
\text { tensen citrate }\end{array}$ & $\begin{array}{l}\text { Starch hydrolysis } \\
\beta \text {-Galactosidase production }\end{array}$ \\
\hline Arginine desimidase & 3-Ketolactose production \\
\hline
\end{tabular}

${ }^{a}$ Also negative in Hugh and Leifson O-F medium.

${ }^{b}$ PWS, Peptone water sugar medium.

- By both lead acetate paper and triple sugar iron agar methods.

${ }^{d}$ Tested with Kovács and Ehrlich reagents.

${ }^{\circ}$ At both $37^{\circ} \mathrm{C}$ and room temperature. and absorbance was recorded on a Pye Unicam AR 25 series linear strip chart recorder. The temperature of the DNA solution was measured at 0.5-degree intervals with a thermistor bead inserted in the sample cuvette and a temperature reading meter. The thermistor bead and meter were calibrated against a thermometer calibrated at the National Physical Laboratories, with both bead and thermometer immersed in an oil bath to a depth of $8 \mathrm{~cm}$. The equation used to relate $T_{m}$ to moles percent guanine plus cytosine $(\mathrm{G}+\mathrm{C})$ was that of Mandel et al. (13):

$$
\begin{aligned}
& \mathrm{mol} \% \mathrm{G}+\mathrm{C}_{\text {unknown }}=\operatorname{mol} \% \mathrm{G}+\mathrm{C}_{\text {reference }} \\
& \quad+\left[\text { slope of equation } \times\left(T_{m_{\text {unknown }}}-T_{m_{\text {reference }}}\right)\right]
\end{aligned}
$$

A value of 2.44 for the slope of the equation was derived from the data of Marmur and Doty (15) and De Ley (7). The average $T_{m}$ from several determinations of the reference DNA extracted from $E$. coli K$12(\mathrm{G}+\mathrm{C}=51 \mathrm{~mol} \%)$ was 91.51 . Substituting values for the slope of the equation and for $T_{m}$ and $\mathrm{mol} \%$ $\mathrm{G}+\mathrm{C}$ of the reference strain in equation 1 gives:

$$
\mathrm{mol} \% \mathrm{G}+\mathrm{C}=51+\left[2.44 \times\left(T_{m}-91.51\right)\right]
$$

\section{RESULTS}

The isolates were gram-negative rods which produced bright yellow colonies on nutrient agar and a pleasant, strong, fruity, characteristic odor. Three colonial types were observed among the strains after incubation for $24 \mathrm{~h}$ on nutrient agar. Strains 4, 5, 6, 7, and 8 produced effuse, spreading colonies 3 to $4 \mathrm{~mm}$ in diameter. These colonies had a raised, shiny center with dull, matt, spreading edges. On further incubation, the whole colony became smooth and shiny (colonial type 1). Colonies of strains 1,3 , and ATCC 4651 showed the same appearance after $24 \mathrm{~h}$ as those of type 1 , but they were smaller, about 1.0 to $1.5 \mathrm{~mm}$ in diameter (colonial type 2 ). On further incubation, the colonies became shiny as those of type 1 but with slightly less luxuriant growth. Colonial type 3 , represented by colonies of strains 2 and 9, were smooth, shiny, and convex with no spreading edge and with a diameter of 0.5 to $1.0 \mathrm{~mm}$ after $24 \mathrm{~h}$; however, after further incubation, the colonies took on the same appearance as those of type 1. After incubation for $24 \mathrm{~h}$ on blood agar, colonies of

TABLE 4. Biochemical characteristics of Flavobacterium odoratum: tests in which there are strain differences

\begin{tabular}{lccc}
\hline \multicolumn{1}{c}{ Characteristic } & $\begin{array}{c}\text { No. of strains } \\
\text { positive }\end{array}$ & $\begin{array}{c}\text { Result of neo- } \\
\text { type strain } \\
\text { (ATCC 4651) }\end{array}$ & $\begin{array}{c}\text { Reference no. of strains } \\
\text { that gave the less common } \\
\text { result }\end{array}$ \\
\hline $\begin{array}{l}\text { Growth on salmonella-shigella (SS) agar } \\
\text { Pigment production on tyrosine agar }\end{array}$ & $1 / 10$ & - & 9 \\
Tween 80 hydrolysis & $3 / 10$ & - & 4,6 , and 8 \\
Gelatin-stab liquefaction & $7 / 10$ & - & 1,9 , and ATCC 4651 \\
Tyrosine hydrolysis & $9 / 10$ & + & 7 \\
\hline
\end{tabular}


all of the strains were nonpigmented and nonhemolytic. The colonial morphology was the same as that observed on nutrient agar except that, of the three strains representing colonial type 2, only colonies of strain 3 had developed a spreading edge at this time. The biochemical test results for the strains are given in Tables 2, 3 , and 4 and are arranged by the tests in which all strains gave a positive or negative result and then by those tests in which the strains differed. The organisms were very homogeneous with respect to their biochemical characteristics, showing differences between the strains in only five of the 70 tests carried out. Although the strains gave negative results for most of the biochemical characters tested (Tables 2,3 , and 4), the organisms have several distinguishing characteristics by which they may be recognized. All of the isolates produce a bright yellow pigment on nutrient agar and give off a characteristic fruity odor. All of the isolates are nonmotile, non-saccharolytic, and produce an alkaline reaction in Hugh and Leifson O-F medium. Casein is digested and extracellular deoxyribonuclease and gelatinase are produced by all of the isolates. Urease is produced, and a particular characteristic of the strains is their ability to reduce nitrite but not nitrate.

Results of susceptibility tests to antimicrobial agents are given in Table 5. The strains were fully resistant to therapeutic levels of streptomycin, gentamicin, kanamycin, ampicillin, carbenicillin, tetracycline, and polymyxin B; fully resistant or moderately resistant to sulfamethoxazole, co-trimoxazole, cephaloridine, erythromycin, and chloramphenicol; and moderately susceptible to nalidixic acid.

The melting temperatures $\left(T_{m}\right)$ and DNA base compositions expressed as the percentage of guanine plus cytosine per total bases present $(\mathrm{mol} \% \mathrm{G}+\mathrm{C}$ ) are given in Table 6. The $\mathrm{G}+\mathrm{C}$ values for the four strains examined ranged from 31.9 to $35.1 \mathrm{~mol} \%$.

\section{DISCUSSION}

Stutzer (18) did not designate a type strain for Bacterium faecale aromaticum when he described this species, which he later renamed Flavobacterium odoratum (19). The extant reference strain of the species, ATCC 4651, conforms to the brief original description of the species $(18,19)$ in colonial appearance, in liquefying gelatin, and in failing to reduce nitrates or to produce hydrogen sulfide. The only result we found at variance with the original description was our failure to demonstrate production of indole. In addition to the agreement with the meager original description, further support for consideration of ATCC 4651 as a strain of $F$. odoratum is provided by the fact that the strain originated from Stutzer (see the American Type Culture Collection Catalogue of Strains, 12th ed., 1976). On the basis of this evidence, we designate ATCC 4651 (= NCTC 11036) as the neotype strain of $F$. odoratum. Although the strain was one of Stutzer's, it cannot be proved that it was one of the strains on which the original description of the species was based.

Our nine field isolates show close conformity to the designated neotype in biochemical characters, susceptibility to antimicrobial agents, and in DNA base composition (Tables 2, 3, 4, 5 , and 6). All isolates produced yellow-pigmented colonies which eventually developed a spreading edge and which produced a characteristic fruity odor. We therefore identify our field strains as members of $F$. odoratum. The differ-

TABLE 5. Susceptibility of Flavobacterium odoratum strains to antimicrobial agents

\begin{tabular}{|c|c|c|c|c|c|c|c|c|c|c|c|c|c|}
\hline \multirow{3}{*}{ Antimicrobial agent } & \multicolumn{13}{|c|}{$\operatorname{MIC}(\mu \mathrm{g} / \mathrm{ml})$ for: } \\
\hline & \multicolumn{10}{|c|}{ Flavobacterium odoratum strain } & \multirow{2}{*}{$\begin{array}{c}\text { Pseudomo- } \\
\text { nas aerugi- } \\
\text { nosa NCTC } \\
10662\end{array}$} & \multirow{2}{*}{$\begin{array}{c}\text { Staphylo- } \\
\text { coccus au- } \\
\text { reus NCTC } \\
6571\end{array}$} & \multirow{2}{*}{$\begin{array}{c}\text { Esche- } \\
\text { richia coli } \\
\text { NCTC } \\
10418\end{array}$} \\
\hline & 1 & 2 & 3 & 4 & 5 & 6 & 7 & 8 & 9 & ATCC & & & \\
\hline $\begin{array}{l}\text { Sulphamethoxa- } \\
\text { zole }\end{array}$ & $>128$ & 4 & 32 & $>128$ & $>128$ & $>128$ & 32 & 128 & $>128$ & 4 & 64 & 2 & 4 \\
\hline Co-trimoxazole & 32 & 4 & 8 & 64 & 128 & 128 & 16 & 64 & 128 & 4 & 32 & 0.5 & 0.5 \\
\hline Streptomycin & $>128$ & 64 & $>128$ & $>128$ & $>128$ & $>128$ & $>128$ & $>128$ & $>128$ & 128 & 32 & 4 & 8 \\
\hline Gentamicin & $>128$ & 128 & $>128$ & $>128$ & $>128$ & $>128$ & $>128$ & $>128$ & $>128$ & 64 & 1 & 0.25 & 1 \\
\hline Kanamycin & $>128$ & $>128$ & $>128$ & $>128$ & $>128$ & $>128$ & $>128$ & $>128$ & $>128$ & $>128$ & 64 & 2 & 2 \\
\hline Ampicillin & $>128$ & 32 & $>128$ & 128 & $>128$ & 128 & 64 & 128 & 128 & 32 & 128 & 0.25 & 4 \\
\hline Carbenicillin & $>128$ & 32 & $>128$ & 128 & $>128$ & 128 & 32 & 128 & $>128$ & 64 & 32 & 1 & 4 \\
\hline Cephaloridine & 16 & 2 & 16 & 8 & 32 & 8 & 4 & 8 & 16 & 1 & $>128$ & 0.03 & 4 \\
\hline Erythromycin & 4 & 0.25 & 2 & 1 & 2 & 1 & 2 & 1 & 64 & 0.25 & 128 & 0.125 & 8 \\
\hline Chloramphenicol & 32 & 4 & 32 & 8 & 32 & 8 & 4 & 8 & 32 & 16 & 16 & 2 & 2 \\
\hline Tetracycline & 16 & 64 & 32 & 64 & 64 & 64 & 64 & 64 & 64 & 32 & 8 & 0.125 & 1 \\
\hline Polymyxin B & $>128$ & $>128$ & $>128$ & $>128$ & $>128$ & $>128$ & $>128$ & $>128$ & $>128$ & 64 & 2 & 128 & 0.25 \\
\hline Nalidixic acid & 16 & 4 & 8 & 4 & 32 & 4 & 4 & 4 & 4 & 8 & 32 & 32 & 1 \\
\hline
\end{tabular}


ences between the strains in colonial morphology resemble those described by Stutzer (18) and Stutzer and Kwaschnina (19).

Salient features for the recognition of this species are production of yellow pigment and fruity odor, production of cytochrome-oxidase, proteinases, deoxyribonuclease, phosphatase and urease, reduction of nitrite, lack of saccharolytic activity, and resistance to carbenicillin, gentamicin, and polymyxin. The DNA base composition ranges between 32 and $35 \mathrm{~mol} \% \mathrm{G}+\mathrm{C}$. Other characters of the proposed neotype and of the field isolates are listed in Tables 2, 3, 4, 5 , and 6 .

Two organisms occasionally isolated from clinical material may be confused with Flavobacterium odoratum: Alcaligenes odorans and isolates of Group IIf of Weaver et al. (21). Both produce alkaline reactions in Hugh and Leifson $\mathrm{O}-\mathrm{F}$ medium and are non-saccharolytic in our ammonium salt sugar medium (except for ethanol in $A$. odorans). Strains of $A$. odorans also produce a fruity odor and reduce nitrite but not nitrate. Strains of Group IIf, which show affinities to both the genus Moraxella and the genus Flavobacterium (17), differ from $F$. odor-

TABLE 6. DNA base compositions of selected strains of $F$. odoratum

\begin{tabular}{ccc} 
Strain no. & $T_{m}\left({ }^{\circ} \mathrm{C}\right)$ of DNA & $\begin{array}{c}\mathrm{Mol} \% \mathrm{G}+\mathrm{C} \text { of } \\
\mathrm{DNA}\end{array}$ \\
\hline 1 & 84.7 & 34.4 \\
2 & 83.7 & 31.9 \\
6 & 83.7 & 31.9 \\
ATCC 4651 & 85.0 & 35.1 \\
\hline
\end{tabular}

atum isolates in producing indole (using Ehrlich reagent). Characters by which $F$. odoratum may be distinguished from $A$. odorans and from Group IIf are given in Table 7.

There is no definite evidence that any of our strains were acting as pathogens. Six of our field strains were isolated from urine, and none of these was considered clinically significant. Unfortunately, the significance of the three field isolates from infected wounds could not be determined as additional clinical details could not be obtained for two of them. Stutzer (18) considered his strains of Bacterium faecale aromaticum to play only a saprophytic role in the human intestine because pathogenicity of his strains in experimental animals could not be demonstrated. Intradermal, intraperitoneal, and intravenous injections of cultures of the organism into mice, guinea pigs, and rabbits produced no demonstrable response (18). Stutzer and Kwaschnina (19) could not recover $F$. odoratum from normal feces, and they isolated strains of this species only from the feces of patients with abdominal typhus, acute gastroenteritis, and relapsing fever. They did not suggest that it followed that the organism was playing a pathogenic role in these patients, but they did consider that isolation of the organism was an indication of pathological processes in the intestine. Following the presently described study, other workers may recognize strains of $F$. odoratum in clinical material, and further studies may perhaps determine if the organism is able to play a pathogenic role. If this proves to be the case, the resistance of $F$. odoratum to a wide

TABLE 7. Characteristics for differentiating between Flavobacterium odoratum and phenetically similar bacteria ${ }^{\alpha}$

\begin{tabular}{|c|c|c|c|}
\hline Characteristic & Group IIf & $\begin{array}{l}\text { Flavobacterium } \\
\text { odoratum }\end{array}$ & $\begin{array}{c}\text { Alcaligenes odor } \\
\text { ans }\end{array}$ \\
\hline Acid from $\mathrm{ASS}^{b}$ ethanol & - & - & + \\
\hline Alkali production on Christensen citrate & - & - & + \\
\hline Casein digestion & + & + & - \\
\hline Deoxyribonuclease production & $11 / 16^{c}$ & + & - \\
\hline Gelatinase production & + & + & - \\
\hline Growth at $42^{\circ} \mathrm{C}$ & + & - & + \\
\hline Growth on cetrimide & - & - & + \\
\hline Growth on Simmons citrate & - & - & + \\
\hline Motility & - & - & $6 / 7$ \\
\hline Nitrite reduction & - & + & + \\
\hline Production of yellow pigment & - & + & - \\
\hline Tween 20 hydrolysis & + & + & - \\
\hline Tyrosine hydrolysis & - & $9 / 10$ & + \\
\hline Urease production & - & + & - \\
\hline
\end{tabular}

${ }^{a}$ The phenotypic results were derived from this study and from NCTC unpublished data. Symbols: + , all strains tested positive; -, all strains tested negative.

${ }^{b}$ ASS, Ammonium salt sugar medium.

c Number of strains showing characters per number of strains tested. 
range of antimicrobial agents (including gentamicin and carbenicillin) to which gram-negative, non-fermentative bacteria might be expected to be susceptible suggests that infections due to this organism might prove difficult to treat.

There is some confusion in the nomenclature of Flavobacterium odoratum. We feel that the following names, which are possible synonyms of $F$. odoratum, may be rejected for the reasons discussed.

Bacterium faecale aromaticum Stutzer 1923, the name originally given to this organism, was changed by Stutzer and Kwaschnina (19) in 1929 to Flavobacterium odoratum so as to conform to the Rules of Botanical Nomenclature as given in Bergey's Manual of Determinative Bacteriology (1). The name Bacterium faecale aromaticum was considered illegitimate by Stutzer and Kwaschnina (19) because the use of the name Bacterium Ehrenberg 1828 as a generic name had been discarded $(1$, p. 28$)$ and because the use of a specific epithet formed of two words contravened the recommendations of the Rules of Botanical Nomenclature (1, p. 25).

Bacillus chromo-aromaticus Eisenberg 1891 was considered by Stutzer (18) not to be identical with $B$. faecale aromaticum since, according to Stutzer (18), B. chromaromaticus (sic) was motile and was nonpigmented on agar. Stutzer (18) attributed the name B. chromo-aromaticus to Gallier (sic), but the latter author (Galtier, 8 ), although being the first to describe the organism, did not propose a name for it.

Bacterium faecale aromatico-indolicum was considered by Stutzer and Kwaschnina (19) to be similar to, though not the same as, $F$. odoratum; these authors attributed the name $B$. faecale aromatico-indolicum to Hartoch and Akinfijew and stated that the differential diagnosis of $B$. esteroaromaticum (vide infra) and $B$. faecale aromatico-indolicum was given by Hartoch and Akinfijew (9). The name Bacterium faecale aromatico-indolicum is illegitimate, both in the use of the name Bacterium for the genus (12; Opinion 4, p. 85) and in the specific epithet faecale aromatico-indolicum because it is formed of two or more words which do not refer to a single concept (12; Rule 12a, p. 15).

Bacterium esteroaromaticum Omeliansky 1923 was also considered by Stutzer and Kwaschnina (19) to be similar to $F$. odoratum. Bacterium esteroaromaticum was later transferred to the genus Flavobacterium (2) as Flavobacterium esteroaromaticum 1 year after the valid publication of the name $\boldsymbol{F}$. odoratum. The specific epithet esteroaromaticum in $B$. esteroaromaticum is legitimate and was validly pub- lished earlier than the specific epithet odoratum in $F$. odoratum; it would therefore take priority if synonymy between the two species names were established. However, the single reference strain of $F$. esteroaromaticum (NCIB 8186) which we have examined, which does not appear to be one of the strains on which the original description of $F$. esteroaromaticum was based, was found to be gram positive.

Alcaligenes marshallii (Buchanan and Hammer 1915) Bergey et al. 1923 was stated in the 6th edition of Bergey's Manual of Determinative Bacteriology (3) to be similar to Flavobac. terium fecale (vide infra), a later synonym of $F$. odoratum. The single reference strain of Alcaligenes marshallii (CCEB 042) which we have examined, and which does not however appear to be one of the strains on which the original description of Alcaligenes marshallii was based, was found to conform to Acinetobacter lwoffii in 68 biochemical characters tested.

Flavobacterium fecale Bergey et al. 1930 is a name given to the organism named earlier by Stutzer (18) in 1923 as Bacterium faecale aromaticum, which Stutzer and Kwaschnina (19) later (1929) changed to Flavobacterium odoratum. The name Flavobacterium fecale, which appears in the 3rd to 6th editions of Bergey's Manual of Determinative Bacteriology (2, 3), is therefore a later objective synonym of Flavobacterium odoratum.

Except for $F$. odoratum, F. esteroaromaticum, and Alcaligenes marshallii, there are, according to the World Directory of Collections of Cultures of Microorganisms (16), no reference strains in existence for any of the above-mentioned species or other names, e.g., Bacterium odoratum, which suggest a possible synonymy with $F$. odoratum. It is possible that our description of the proposed neotype strain of $F$. odoratum may fit the generally meager early descriptions given for some of the above-mentioned species, but since (except for the cases cited) there are no reference strains available of any of these species, we consider it more appropriate to propose a neotype strain for $F$. odoratum since the strain chosen (ATCC 4651) conforms in its characters to the original description of the species and traces back to the author of the species.

Two of our field strains have also been deposited in the NCTC: CL41/66 as NCTC 11179 and CL229/67 as NCTC 11180 .

Since originally submitting this manuscript, three cultures of group M-4f (20) have been received from R. E. Weaver (B7249, toe; B9856, sputum; B7942, urine). We have examined these three strains and find that they are strains of 
Flavobacterium odoratum; therefore $F$. odoratum and group M-4f are the same taxon.

\section{ACKNOWLEDGMENTS}

We are extremely grateful to Helen T. March for assistance with the translation of the German text of the papers by Stutzer (18) and by Stutzer and Kwaschnina (19). We thank the Department of Health and Social Security, whose grant for the identification of bacteria using a computer enabled this work to be carried out. Our thanks are also due to all those who sent us strains of the study organisms for identification, especially those who also kindly provided additional clinical details relating to the isolation of their strains.

\section{LITERATURE CITED}

1. Bergey, D. H., F. C. Harrison, R. S. Breed, B. W. Hammer, and F. M. Huntoon. 1926. Bergey's manual of determinative bacteriology, 2nd ed. Baillière, Tindall \& Cox, London.

2. Bergey, D. H., F. C. Harrison, R. S. Breed, B. W. Hammer, and F. M. Huntoon. 1930. Bergey's manual of determinative bacteriology, 3rd ed. Baillière, Tindall \& Cox, London.

3. Breed, R. S., E. G. D. Murray, and A. Parker Hitchens. 1948. Bergey's manual of determinative bacteriology, 6th ed. Baillière, Tindall \& Cox, London.

4. Brenner, D. J., G. R. Fanning, A. V. Rake, and K. E. Johnson. 1969. Batch procedure for thermal elution of DNA from hydroxyapatite. Anal. Biochem. 28:447-459.

5. Buchanan, R. E., J. G. Holt, and E. F. Lessel, Jr. 1966. Index Bergeyana. E. \& S. Livingstone Limited, London.

6. Cowan, S. T. 1974. Cowan and Steel's manual for the identification of medical bacteria, 2nd ed. University Press, Cambridge.

7. De Ley, J. 1970. Re-examination of the association between melting point, buoyant density, and chemical base composition of deoxyribonucleic acid. J. Bacteriol. 101:738-754.

8. Galtier, M. 1888. Sur un microbe pathogène chromoaromatique. C. R. Acad. Sci. Paris 106:1368-1370.

9. Hartoch, O., and Akinfijew. 1925. Zur Frage über die Aromabildenden Mikroben. J. Mikrobiol. Pathol. Infektionskr. 2, H.I (russ.), fide Stutzer and Kwaschnina (19).
10. Holmes, B., S. P. Lapage, and H. Malnick. 1975. Strains of Pseudomonas putrefaciens from clinical material. J. Clin. Pathol. 28:149-155.

11. King, E. O., M. K. Ward, and D. E. Raney. 1954. Two simple media for the demonstration of pyocyanin and fluorescin. J. Lab. Clin. Med. 44:301-307.

12. Lapage, S. P., P. H. A. Sneath, E. F. Lessel, V. B. D. Skerman, H. P. R. Seeliger, and W. A. Clark. 1975. International code of nomenclature of bacteria. American Society for Microbiology, Washington, D. C.

13. Mandel, M., L. Igambi, J. Bergendahl, M. L. Dodson, and E. Scheltgen. 1970. Correlation of melting temperature and cesium chloride buoyant density of bacterial deoxyribonucleic acid. J. Bacteriol. 101:331-338.

14. Marmur, J. 1961. A procedure for the isolation of deoxyribonucleic acid from micro-organisms. J. Mol. Biol. 3:208-218.

15. Marmur, J., and P. Doty. 1962. Determination of the base composition of deoxyribonucleic acid from it's thermal denaturation temperature. J. Mol. Biol 5:109-118

16. Martin, S. M., and V. B. D. Skerman. 1972. World directory of collections of cultures of microorganisms. Wiley-Interscience, New York.

17. Owen, R. J., and J. J. S. Snell. 1973. Comparison of group IIf with Flavobacterium and Moraxella. Antonie van Leeuwenhoek J. Microbiol. Serol. 39:473-480.

18. Stutzer, M. J. 1923. Zur Frage über die Fäulnisbakterien im Darm. Zentralbl. Bakteriol. Parasitenkd. Infektionskr. Hyg. Abt. 1 Orig. 91:87-90.

19. Stutzer, M., and A. Kwaschnina. 1929. In Aussaaten aus den Fäzes des Menschen gelbe Kolonien bildende Bakterien (Gattung Flavobacterium u.a.). Zentralbl. Bakteriol. Parasitenkd. Infektionskr. Hyg. Abt. 1 Orig. 113:219-225.

20. Tatum, H. W., W. H. Ewing, and R. E. Weaver. 1974 Miscellaneous Gram-negative bacteria, p. 270. In E. H. Lennette, E. H. Spaulding, and J. P. Truant (ed.), Manual of clinical microbiology, 2nd ed. American Society for Microbiology, Washington, D. C.

21. Weaver, R. E., H. W. Tatum, and D. G. Hollis. 1972 The identification of unusual pathogenic Gram-negative bacteria. (Elizabeth $\mathrm{O}$. King). Preliminary revision. Center for Disease Control monograph, Atlanta, Ga.

22. Weeks, O. B. 1974. Genus Flavobacterium Bergey et al. 1923, p. 357. In R. E. Buchanan and N. E. Gibbons (ed.), Bergey's manual of determinative bacteriology, 8th ed. Williams and Wilkins Co., Baltimore. 